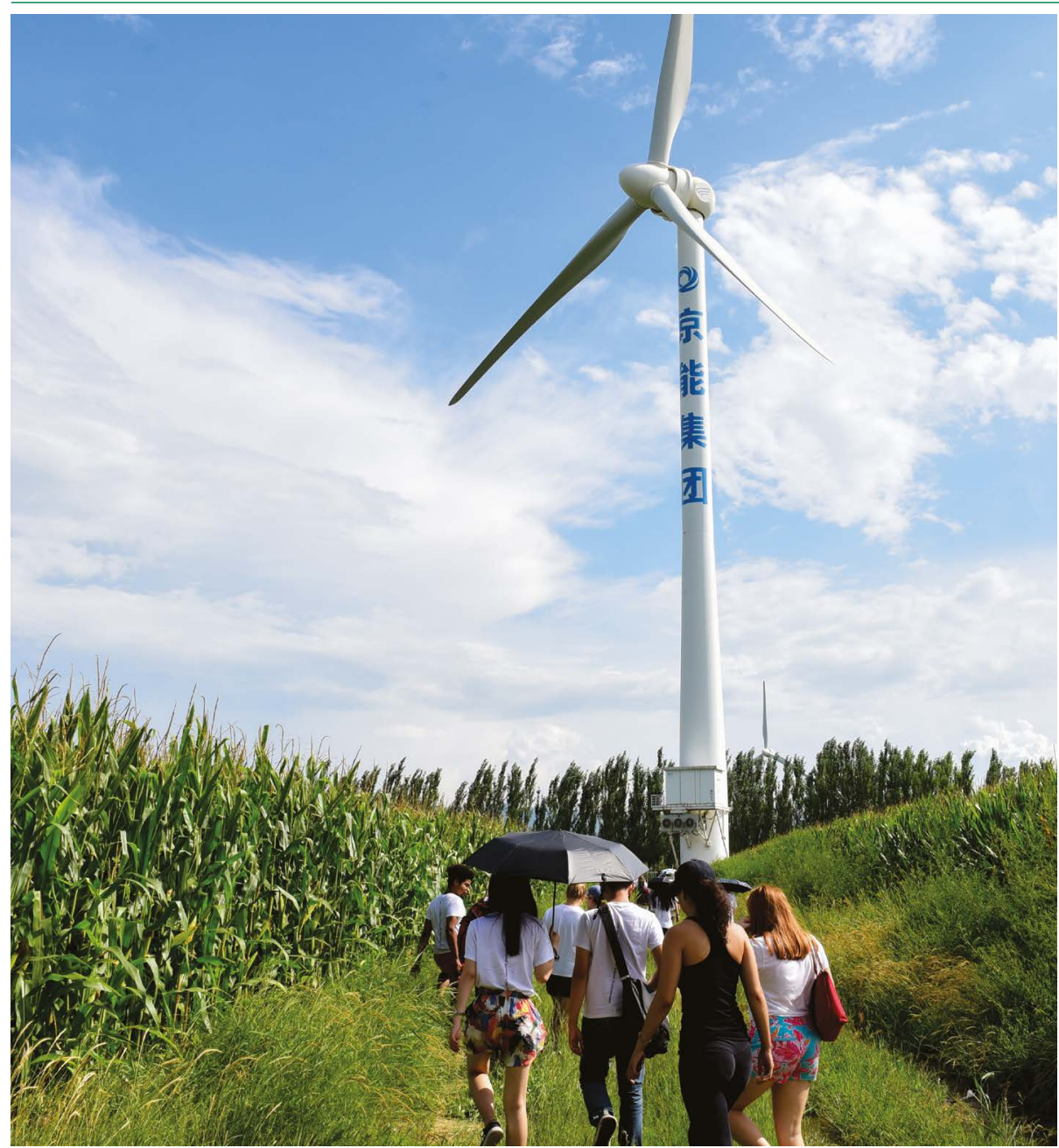

Shared endeavours, such as this energy study by the Havard China Project, continue to flourish.

\title{
Science weathers political ill wind
}

\section{Despite government tensions, research collaboration between China and the United States remains strong. By Chris Woolston}

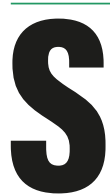
ome projects are too big for a single lab. Or, for that matter, a single country. Hongkui Zeng, a neuroscientist at the Allen Institute for Brain Science in Seattle, Washington, is working on an ambitious project that spans the Pacific. Her team is attempting to untangle the subtle structural differences among groups of neurons in the mouse neocortex, where higher cognitive functioning such as sensory perception and spatial reasoning is processed. The pursuit requires major assistance from scientists in China, whose international research presence is strong, despite growing mistrust from the US government.

To get a clearer picture of the mouse neocortex, Zeng depends on high-resolution neuron images from Huazhong University of Science and Technology, in China (HZAU). "They have a unique bioimaging centre," she says. Access to these images allows researchers to more closely examine the shape and structure of the axons that carry electrical messages from neurons. "The morphology helps us understand how neurons form networks and communicate with each other," she says. "It's critical information."

In science as in cortexes, networks are crucial. According to the Nature Index, connections between the United States and China are stronger than ever. The number of papers co-authored by the two countries in the 82 high-quality journals tracked by the index leapt from 3,413 in 2015 to 4,631 in 2018. Chinese authors collaborated with researchers in the United States more often than in any other region, and China is second only to the European Union as the collaborator of choice for researchers in the United States.

These partnerships have formed against a backdrop of political tensions, economic tariffs, and even fears of academic espionage. In September, US federal prosecutors announced the arrest of Zhongsan Liu, head of the New York office of the China Association for International Exchange of Personnel, for his alleged involvement in a conspiracy to fraudulently obtain US visas for Chinese government employees. A month earlier, the Federal Bureau of Investigation arrested Chinese chemist, Feng Tao, an associate professor at the University of Kansas, for allegedly failing to disclose his full-time employment with Fuzhou University in China.

Earlier this year, the MD Anderson Cancer Center in Houston, Texas, sacked three Chinese scientists over alleged theft of research data for China, and Science magazine reported that the US National Institutes of Health (NIH) sent letters to 77 institutions warning of collaboration with scientists who may have ties to foreign governments, including China.

Such incidents have caused consternation and unease among Chinese researchers and their collaborators in the United States, Zeng says. But scientific cooperation remains strong for a fundamental reason: each country has intellectual and material scientific resources that transcend political boundaries. "Science needs a free exchange of information," says Zeng. "There shouldn't be any barriers."

Cooperation flows in both directions. In 2018, Zeng, and Allen Institute geneticist, Linda Madisen, were co-authors on a paper that presented a three-dimensional atlas of the cholinergic system in the mouse brain, an important model for Alzheimer's disease research. The study, published in the Proceedings of the National Academy of Sciences, was led by researchers at HZAU, and was based on mouse cell lines created by Zeng and Madisen in the United States. "We develop tools and 
resources and share them with the scientific community," says Zeng. “They should be available to anybody."

Despite its high-profile warnings regarding foreign research partnerships, collaboration also continues at the NIH. Christopher Buck, a virologist at the National Cancer Institute's Center for Cancer Research, a division of the $\mathrm{NIH}$, credits Chinese researchers for playing a major role in his latest finding: the discovery of 12 new types of small DNA tumour viruses, infectious agents with the potential to cause cancer. He found the first hints of a new virus in fish DNA sequenced by researchers at the BGI Academy of Marine Sciences in Shenzhen, China, led by Chao Bian.

\section{Available to anybody}

Bian's team is part of BGI Marine, the agricultural arm of China's BGI Group, a gene-sequencing company that runs the largest genetics research centre in the world. The BGI researchers didn't have viruses in their sights when they originally shared DNA sequences with the NIH researchers. They were investigating the genetic make-up of the green Asian arowana (Scleropages formosus), a prized aquarium fish that can fetch several hundred thousand dollars on the market.

When Buck informed them of the intriguing viral sequences, they returned to their samples and sequenced the entire viral genome. "They kindly and bravely trusted that this strange person from across the ocean had a valid hypothesis," he says. A preprint of the study was published in bioRxiv in August.
BGI's sequencing powers fuel a significant portion of China-US scientific collaboration. In the Nature Index, BGI is involved in $7 \%$ (see 'Big picture science', S28) of collaborative articles involving at least one corporate institution publishing in genetics between 2015 and 2018.

"I have great admiration for BGI," Buck says. “They're sequencing all sorts of interesting things, and they're sharing what they find. It takes teams of specialists to look at the data and see what's going on." He adds that no one at the NIH has ever warned him about sharing sensitive materials with researchers from

\section{"They kindlly and bravely trusted that thisstrange person from across the ocean had a valid hypothesis."}

China or any other country. "I have no secrets," says Buck. "Taxpayers are paying me to create scientific knowledge and broadcast it as widely as possible."

Harvard University's long history of scholarship on China and deep ties with the country has set the stage for ongoing cooperation in many scientific fields, says Michael McElroy, a climate scientist and chair of the Harvard China Project, a joint effort of several Harvard colleges established in 1993 to understand and tackle energy, environmental and economic issues in China and beyond.

For the past few decades, hundreds of
Chinese graduate students who came to Harvard as part of the project have returned to their home country to become government officials or scientists. Those students are part of a larger trend: nearly 10,000 researchers, mostly of Chinese origin, moved from the United States to China in 2017 alone.

\section{Great admiration}

Those networks have led to many collaborations, including a Nature Sustainability paper published in July suggesting that China may be five to ten years ahead of schedule in meeting its Paris Agreement pledge to curb carbon dioxide emissions by 2030. The paper was co-authored by McElroy and a group of Chinese researchers led by Haikun Wang, a researcher at Nanjing University and one of McElroy's former graduate students.

McElroy says that much of the funding for the Harvard China Project now comes from the Harvard Global Institute, a sign of change. "In the early days, we had funding from the National Science Foundation and NASA," he says. "Today, there's no possibility of getting funding from official US sources for China-related work. It's discouraged in Washington."

Despite the sometimes uneasy climate, McElroy predicts that collaboration between US and Chinese scientists will continue to propel science in both countries. "The strength of cooperative scholarship has not declined," he says. "If anything, it's growing."

Chris Woolston is a freelance science writer in Billings, Montana.

\section{PROLIFIC PAIRING}

Growth in the number and strength of institution-to-institution research relationships shows no sign of slowing, despite political tensions between the US and China.

\section{Bilateral partnerships}

Research relationships between US and Chinese institutions grew strongly in the 6 years to 2018 .

12

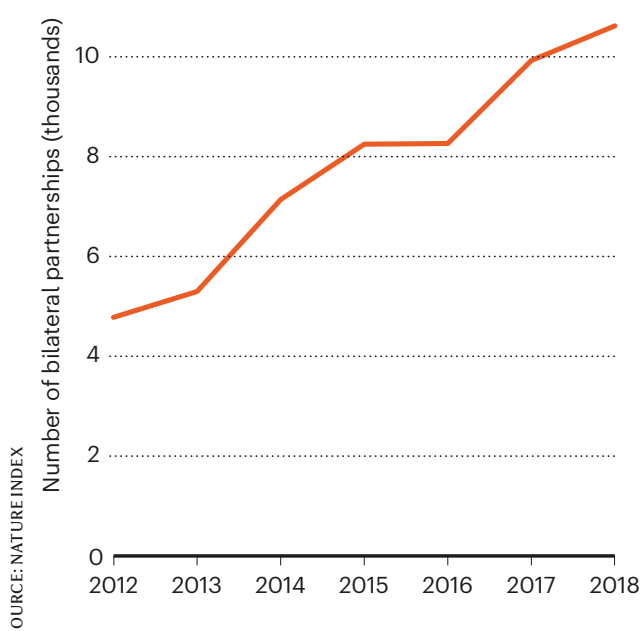

Top cooperators

Among the most productive US-China partnerships in high-quality research in 2018,7 of the top 10 involve the Chinese Academy of Sciences (CAS).

US institutions

Chinese institutions

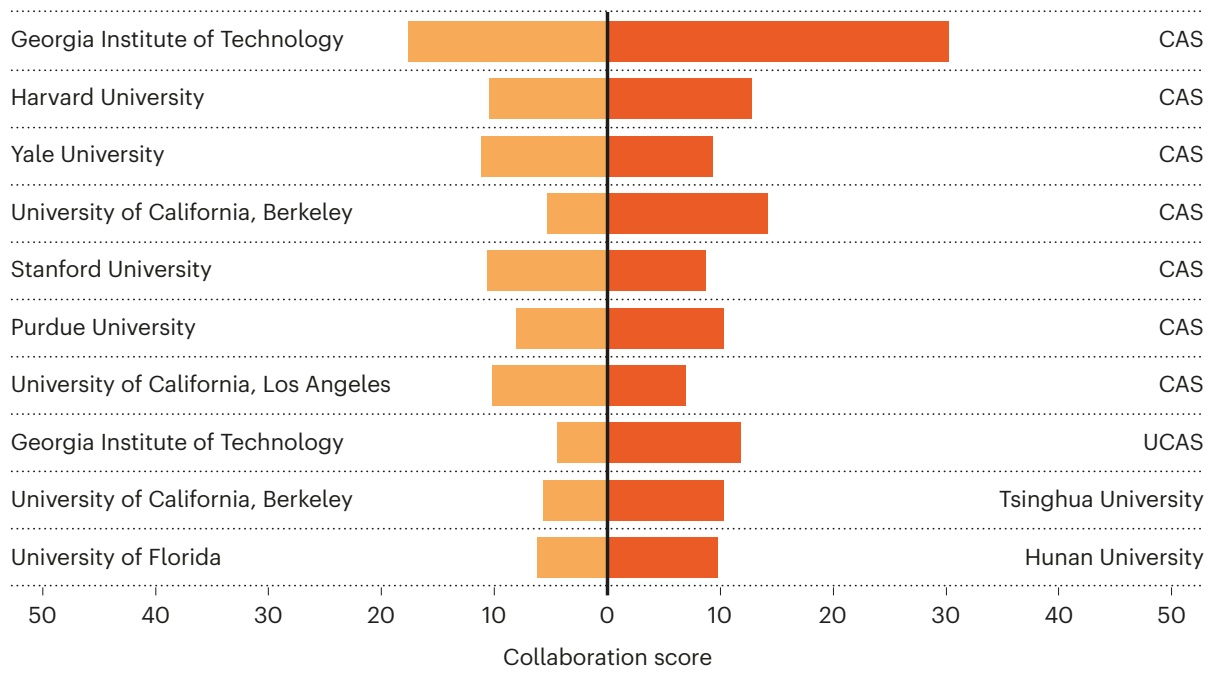

